\title{
Burdur yöresi ceviz (Juglans regia L.) bahçelerinin beslenme durumunun belirlenmesi
}

\section{Determination of nutritional status in walnut (Juglans regia L.) orchards in Burdur province}

\author{
Şerife YÖN(i), İlker SÖNMEZ®i \\ ${ }^{1}$ Akdeniz Üniversitesi, Ziraat Fakültesi, Toprak Bilimi ve Bitki Besleme Bölümü, 07058, Antalya \\ Sorumlu yazar (Corresponding author): İ. Sönmez, e-posta (e-mail): ilkersonmez@akdeniz.edu.tr \\ Yazar(lar) e-posta (Author e-mail): serife.trgt@gmail.com
}

\section{MAKALE BİLGİSİ}

Alınış tarihi 28 Mayıs 2020

Düzeltilme tarihi 02 Ekim 2020

Kabul tarihi 02 Ekim 2020

\section{Anahtar Kelimeler:}

Burdur

Besin elementleri

Ceviz

Toprak verimliliği

\begin{abstract}
ÖZ
$\mathrm{Bu}$ çalışma, Burdur yöresinde ceviz (Juglans regia L.) yetiştiriciliği yapılan bahçelerde bitkilerin beslenme durumlarının ortaya konulması amacıyla yapılmıştır. $\mathrm{Bu}$ amaçla 20 bahçeden yaprak örnekleri ve 2 farklı toprak derinliğinden $(0-30 \mathrm{~cm}$ ve $30-60 \mathrm{~cm})$ toprak örnekleri alınmıştır. Yaprak örneklerinde makro ve mikro element analizleri; toprak örneklerinde ise $\mathrm{pH}$, elektriksel iletkenlik (EC), kireç $\left(\mathrm{CaCO}_{3}\right)$, organik madde, bünye, makro ve mikro element analizleri yapılmıştır. Yaprak analizi sonuçlarına göre; azot (N), fosfor (P), bakır $(\mathrm{Cu})$ ve çinko $(\mathrm{Zn})$ içerikleri noksan bulunurken, potasyum $(\mathrm{K})$, kalsiyum $(\mathrm{Ca})$, magnezyum $(\mathrm{Mg})$, demir $(\mathrm{Fe})$ ve mangan $(\mathrm{Mn})$ içerikleri yeterli bulunmuştur. Toprak analizlerine göre toprakların büyük çoğunluğunun tınlı bünyeye sahip olduğu bulunmuş ve toprak reaksiyonu hafif alkali-nötr sınıflarında değişim göstermiștir. Her iki toprak derinliğinde de herhangi bir tuzluluk sorunu saptanmamıştır. Toprakların büyük çoğunluğunda aşırı ve yüksek kireç bulunması, yetiştiricilik ve beslenme açısından bazı sorunların oluşabileceğini göstermektedir. Toprak örneklerinin organik madde içerikleri az humuslu ve humusça fakir, toplam azot bakımından topraklar iyi ve çok iyi, alınabilir P bakımından ise değişkenlik göstermiş ve topraklarda kısmen yetersizlik saptanmıştır. Toprakların yarayışı $\mathrm{K}$, $\mathrm{Ca}$ ve $\mathrm{Mg}$ içerikleri büyük oranda yeterli olarak tespit edilmiştir. Alınabilir Fe ve Zn içerikleri yetersiz olup alınabilir $\mathrm{Mn}$ ve $\mathrm{Cu}$ yeterli bulunmuştur. Ceviz yetiştiriciliğinde önemli potansiyele sahip olan Burdur yöresinde gübrelemenin yaprak ve toprak analizlerini dikkate alınarak yapılmamasından dolayı beslenme durumlarında kısmen eksiklikler belirlenmiştir. Analize dayalı yeterli ve dengeli bitki besleme uygulamaları ile verimliliğin ve sürdürülebilirliğin artırılabileceği öngörülmektedir.
\end{abstract}

\section{ARTICLE INFO}

Received 28 May 2020

Received in revised form 02 October 2020 Accepted 02 October 2020

\section{Keywords:}

Burdur

Nutrient elements

Walnut

Soil productivity

\begin{abstract}
This study was carried out to determine the nutritional status of the walnut orchards (Juglans regia L.) in Burdur province. For this purpose, plant samples from 20 orchards and soil samples from two different soil depths $(0-30 \mathrm{~cm}$ and $30-60 \mathrm{~cm})$ were taken. Macro and micro elements in walnut plants and organic matter, texture, $\mathrm{pH}$, electrical conductivity (EC), lime, macro and micro elements in soil samples were analyzed. According to walnut plant analysis; the potassium $(\mathrm{K})$, calcium $(\mathrm{Ca})$, magnesium $(\mathrm{Mg})$, iron $(\mathrm{Fe})$ and manganese $(\mathrm{Mn})$ contents were sufficient in walnut plants, whereas the nitrogen $(\mathrm{N})$, phosphorus $(\mathrm{P})$, zinc $(\mathrm{Zn})$ and copper $(\mathrm{Cu})$ contents were deficient. According to results, soils generally had loam texture generally and $\mathrm{pH}$ values were found slightly alkaline to neutral range. EC values were low and the majority of the soils were excessively and highly calcareous that can cause some problems in terms of cultivation and nutrition. Organic matter contents of soils were found to be low humus and total $\mathrm{N}$ contents were sufficient. Available $\mathrm{P}$ is partially insufficient; the extractable $\mathrm{K}, \mathrm{Ca}$ and $\mathrm{Mg}$ contents were above the sufficiency threshold. Available Fe and $\mathrm{Zn}$ weren't deficient; available $\mathrm{Mn}$ and $\mathrm{Cu}$ contents were sufficient levels. In Burdur province, which has an important potential in walnut cultivation, deficiencies in nutritional status of walnut orchards were partly determined due to the lack of leaf and soil analysis-based fertilization. It is predicted that productivity and sustainability can be increased by adequate and balanced fertilization practices based on the analysis.
\end{abstract}




\section{Giriş}

İnsan beslenmesinde üç temel gıda grubu olan; yağlar, proteinler ve karbonhidratların önemi büyüktür. Bu temel gida maddeleri bakımından yeterli ve dengeli bir şekilde beslenen insanların sağlıklı bir yaşam sürmeleri ve bu durumu uzun süre sağlayabildikleri bildirilmektedir (Şen 2011). İnsan beslenmesinde sağlıklı beslenme kavramının öne çıktığı son yıllarda özellikle sert kabuklu meyvelerin besin bütçelerinde yer aldığı ve yaşam kalitesinde önemli katkılar sağladığı bildirilmektedir. $\mathrm{Bu}$ kapsamda cevizin önemi daha da artmaktadır. Çünkü cevizin yağ ve protein içeriğinin yüksek olması, gıda sektöründe, işlenmiş ürünlerde, farmakoloji ve kozmetik sektöründe tercih edilmesi nedeniyle kullanımı daha da yaygınlaşmaktadır. Yapılan araştırmalara göre $100 \mathrm{~g}$ ceviz, yaklaşık $14 \mathrm{~g}$ sindirilebilir protein içerip bitkisel protein ihtiyacını karşılamaktadır. Ceviz, yağ ve protein yönünden badem ve findıktan daha zengindir ve sağlıklı bir yaşam için mutlaka tüketilmesi gereken gidalardan birisidir (Akça 2012).

Dünya ceviz üretimi 999081 ha alanda üretilen ceviz miktarı ile 3458046 tondur. Dünyada üretim alanına göre birinci sırada Çin (425000 ha), ikinci sırada Amerika Birleşik Devletleri (ABD) (113120 ha), üçüncü sirada Türkiye (108767 ha), dördüncü sırada Meksika (72563 ha) ve beşinci sırada İran (57386 ha) gelmektedir. Dünya ceviz üretiminde ise 1700000 ton ile Çin başı çekmekte, ikinci sıraya 453988 ton ile İran yerleşmiş, 420000 ton ile üçüncü sıraya $A B D$ ve 212140 ton ile dördüncü sıraya Türkiye yerleşmiştir (FAO 2017). Türkiye y1llık ceviz üretimi TUİK rakamlarına göre 2018 yılında 215000 ton civarındadır. Burdur ili de ceviz üretiminde yörede önemli bir potansiyele sahiptir ve 2019 yılında toplam ceviz üretim miktarı 4358 ton olarak belirlenmiştir (TUIKK 2019).

Ceviz değişik iklim koşullarına adaptasyonu iyi bir bitki olup, soğuklama ihtiyacı 400-1800 saat arasında değişmekte, genellikle denizden yüksekliği $1700 \mathrm{~m}$ olan lokasyonlarda yetişmektedir (Akça 2012). Cevizde verim ve kaliteyi artırmak için uygun iklim ve toprak şartlarında yetiştiricilik yapılmalıdır. Sulama, budama ve gübreleme gibi uygulamalar zamanında ve gerektiği miktarda yapılmalı, hastalık ve zararlılar ile mücadele edilmeli ve çevresel stres koşullarına karşı önlem alınmalıdır. Drossopoulos ve ark. (1996) tarafindan ceviz bahçelerinin beslenme durumunu belirlemek için yapılan bir araştırmada, 51 farklı ceviz bahçesinden alınan yaprakların bitki besin elementlerinin düzeyleri; $\mathrm{N}$ : $16-35 \mathrm{mg} \mathrm{g}^{-1}, \mathrm{P}: 1.3-2.1 \mathrm{mg} \mathrm{g}^{-1}, \mathrm{~K}$ : 8.6-18.5 $\mathrm{mg} \mathrm{g}^{-1}$, Ca: $26.1-41.4 \mathrm{mg} \mathrm{g}^{-1}, \mathrm{Mg}: 3.7-4.5 \mathrm{mg} \mathrm{g}^{-1}$, Fe: 176-342 mg kg-1, Zn: 37.5-66.7 mg kg-1, Mn: 93-171 mg kg-1, $\mathrm{Cu}: 7.5-15 \mathrm{mg} \mathrm{kg}^{-1}$ arasında belirlenmiştir.

Mills ve Jones (1996), ceviz yapraklarında olması gereken bazı makro ve mikro bitki besin elementi düzeylerinin $\mathrm{N}$ : \%2.47-2.98, P: \%0.16-0.24, K: \%1.32-1.47, Ca: \%1.90-2.01, Mg: \%0.51-0.63, Fe: 69-129 mg kg-1, Mn: 207-274 mg kg-1, Zn: $33-55 \mathrm{mg} \mathrm{kg}^{-1}$ ve $\mathrm{Cu}: 10-12 \mathrm{mg} \mathrm{kg}^{-1}$ aralığında olması gerektiğini bildirmişlerdir. Ponder ve ark. (1998), toprak analizine bağlı olarak ceviz ağaçlarına yılda en az bir defa azotlu gübrelemenin mutlaka yapılması gerektiğini, ayrıca topraktaki yarayışlı miktarlarına göre $\mathrm{P}$ ve $\mathrm{K}$ gübrelemesinin de gerekliliğini bildirmişlerdir. Adıman (2013), tarafından yapılan bir araştırmada; Tokat-Niksar' da ceviz bahçelerinde yaprakların \%69'unda $\mathrm{N}, \% 57$ 'sinde $\mathrm{P}$, \%42'sinde $\mathrm{K}, \% 71$ 'inde $\mathrm{Mg}$, $\% 74$ 'ünde $\mathrm{Ca}, \% 33$ 'ünde $\mathrm{Fe}$, \%21'inde $\mathrm{Zn}, \% 93$ 'ünde $\mathrm{Mn}$ ve $\% 100$ 'ünde $\mathrm{Cu}$ noksanlığı olduğu belirlenmiştir. Uygur ve ark. (2013) 12 ceviz genotipinin subtropikal iklim koşullarındaki Hatay ekolojisinde aynı toprak koşullarında yaprak besin elementi içeriğinin $\mathrm{N}: 19.13-25.14 \mathrm{~g} \mathrm{~kg}^{-1}$, P: $2.03-2.45 \mathrm{~g} \mathrm{~kg}^{-1}$, $\mathrm{K}: 7.16-9.40 \mathrm{~g} \mathrm{~kg}^{-1}$, Ca: 7.85-9.83 $\mathrm{g} \mathrm{kg}^{-1}, \mathrm{Mg}: 2.23-2.76 \mathrm{~g} \mathrm{~kg}^{-1}$, $\mathrm{Na}: 106.35-154.02 \mathrm{mg} \mathrm{kg}^{-1}$, Fe: $113.49-262.29 \mathrm{mg} \mathrm{kg}^{-1}, \mathrm{Zn}$ : 13.92-20.11 mg kg-1, Mn: 143.17-421.08 mg kg-1 ve Cu: $5.85-$ $8.95 \mathrm{mg} \mathrm{kg}^{-1}$ arasında değiştiğini bildirmişlerdir.

$\mathrm{Bu}$ araştırma, Burdur ili ceviz yetiştiriciliği yapılan bahçelerinin yaprak ve toprak örneklerinin analiz sonuçlarının değerlendirilmesi ile bazı verimlilik parametrelerinin ve beslenme durumlarının belirlenmesi amacıyla yürütülmüştür.

\section{Materyal ve Yöntem}

\subsection{Materyal}

Araştırma materyalini Burdur ilinde ceviz yetiştiriciliğinin yoğun olarak gerçekleştirildiği Bucak, Çeltikçi, Ağlasun, Altınyayla ve Tefenni ilçelerine seçilen 20 farklı bahçeden 20 yaprak örneği, $0-30 \mathrm{~cm}$ ve $30-60 \mathrm{~cm}$ derinliklerden olacak şekilde toplam 40 adet toprak örneği oluşturmaktadır.

\subsection{Yöntem}

Burdur yöresinde ceviz yetiştiriciliği yapılan 20 bahçeden alınan yaprak örnekleri cevizde yaprak örneği alma zamanı olarak bildirilen çiçeklenme sonrası 6-8. haftada olgun sürgünlerdeki orta bileşik yaprak çiftlerinden ağaçların dört tarafından olacak şekilde güneş gören dalların omuz hizasındaki uç sürgünlerin orta yaprakları alınmıştır (Ponder 2004; Arslan 2012). Yaprak örnekleri çeşme suyu ve saf su ile yıkanmış ve $65-70^{\circ} \mathrm{C}$ 'de sabit ağırlığa gelinceye kadar etüvde kurutulmuştur. Daha sonra bitki öğütme değirmeninde öğütülerek homojen hale getirilmişlerdir. Alınan yaprak örneklerinin toplam $\mathrm{N}$ analizi Modifiye Kjeldahl metoduna göre, toplam P, K, Ca, Mg, Fe, Zn, $\mathrm{Mn}$ ve $\mathrm{Cu}$ konsantrasyonları yaş yakma yöntemi ile elde edilen süzükten indüktif eşleşmiş plazma optik emisyon spektrofotometresi (Perkin Elmer Optima 7000DV - ICP OES) ile yapılan okuma sonucunda belirlenmiştir (Kacar ve İnal 2008).

Toprak örnekleri Jackson (1967) tarafindan belirtilen esaslara göre örnekleme yapılan bahçeyi temsil edecek şekilde $0-30 \mathrm{~cm}$ ve $30-60 \mathrm{~cm}$ olmak üzere iki farklı derinlikten alınmış ve Chapman ve ark. (1961)'e göre analize hazır hale getirilmiştir. Toprak örneklerinde bünye (Bouyoucos 1951), pH ve EC 1:2.5 toprak su karışımında (Jackson 1967, Jackson 1959), $\mathrm{CaCO}_{3}$ (Çağlar 1949), organik madde yaş oksidasyon (Black 1965), toplam N Kjeldahl yönteminde (Kacar 1995), $\mathrm{NaHCO}_{3}$ ile ekstrakte edilebilir P (Olsen ve Sommers 1982), $\mathrm{NH}_{4}$ Asetat ile ekstrakte edilebilir K, Ca ve Mg (Kacar 2009), DTPA ile ekstrakte edilebilir Fe, $\mathrm{Zn}, \mathrm{Cu}$ ve Mn (Lindsay ve Norvell 1978) analizleri gerçekleştirilmiştir. Analizlerden elde edilen veriler ceviz için belirlenen sınır değerleri ile karşılaştırılarak ceviz bahçelerinin beslenme durumları değerlendirilmiştir. Ayrıca ceviz yaprak örneklerinin besin elementleri içerikleri ile toprak örneklerinin fiziksel ve kimyasal özellikleri arasındaki önemli ilişkiler korelasyon (Pearson katsayıs1) analizine tabi tutularak regresyon denklemleri elde edilmiş ve ilişkiler değerlendirilmiştir.

\section{Bulgular ve Tartışma}

\subsection{Yaprak analiz sonuçları}

Burdur yöresinde seçilen 20 adet ceviz bahçesinden alınan yaprak örneklerinin analiz sonuçlarına göre minimum, maksimum ve ortalama değerler Çizelge 1'de verilmiştir. 
Yaprak örneklerinin toplam N kapsamları \%2.19-3.18 arasında değişmektedir. Ceviz bahçelerinden alınan yaprak örneklerinin $\mathrm{N}$ analiz sonuçları Jones ve ark. (1991)'na göre yeterli olarak görülen \%2.50-3.25 sınır değerleri ile karşılaştırıldığında ceviz bahçelerinin toplam $\mathrm{N}$ kapsamlarının \%45'inin yeterli ve $\% 55$ 'inin ise noksan olduğu görülmektedir (Çizelge 2). Yıldız ve Uygur (2016) Uşak'ta ceviz yapraklarındaki N içeriklerinin \%2.01-3.40 aralığında ve Solmaz (2014) Tekirdağ'da ceviz yaprak örneklerinde $\mathrm{N}$ içeriklerinin \%0.99-3.02 arasında değiştiğini belirlemişlerdir. Adıman (2013) Tokat yöresindeki ceviz yapraklarının $\mathrm{N}$ içeriklerinin (\%1.72-4.71) \%69'unun noksanlık düzeyinde olduğunu bildirmiştir.

Yaprak örneklerinin tamamının toplam $\mathrm{P}$ yönünden yeterli olduğu ve toplam P kapsamlarının \%0.13-0.19 arasında değiştiği belirlenmiştir (Çizelge 1, 2) Solmaz (2014) Tekirdağ ilindeki ceviz bahçelerinden alınan yaprak örneklerinin $\mathrm{P}$ kapsamlarının \%0.11-0.32 arasında değiştiğini, Yıldız ve Uygur (2016) Uşak'ta ceviz bahçelerinden alınan yaprakların P içeriğinin \%0.07 ile \%0.20 arasında değiştiğini bildirmişlerdir. Ceviz bahçelerinden alınan yaprak örneklerinin \%95'inin $\mathrm{K}$ beslenmesi yönünden yeterli olduğu ve kuru maddede toplam $\mathrm{K}$ kapsamlarının \%1.10-2.74 arasında değiştiği tespit edilmiştir. Solmaz (2014) Tekirdağ'da ceviz yaprak örneklerinin K kapsamlarının \%1.02-2.18 arasında değiştiğini belirtmiştir.

Yaprak örneklerinin toplam Ca kapsamlarının \%2.01-3.91 arasında değiştiği görülmüştür (Çizelge 1). Jones ve ark. (1991) tarafından ceviz için belirlenen $\mathrm{Ca}$ sınır değerleri ile karşıllaştırıldığında yaprak örneklerinin tamamının yeterli düzeyde Ca içerdiği belirlenmiştir (Çizelge 2). Başaran (2005) Çankırı'da ceviz yaprak örneklerinde $\mathrm{Ca}$ içeriklerinin yeterli olduğu bildirilmiştir. Solmaz (2014) ceviz bahçelerinden alınan yaprak örneklerinin Ca içeriğinin \%0.31-2.86, Yıldız ve Uygur (2016) ise \%0.80 ile \%2.54 arasında değiştiğini belirtmişlerdir. Toplam Mg kapsamı bakımından yaprak örneklerinin \%100'ünün yeterli düzeyde olduğu ve toplam $\mathrm{Mg}$ kapsamlarının \%0.41-0.97 arasında değiştiği saptanmıştır (Çizelge 1). Adıman (2013) Tokat'ta ceviz yapraklarındaki Mg konsantrasyonlarının \%0.25-0.66 arasında değiştiğini ve ortalama değerin ise $\% 0.44$ olduğunu bildirmiştir.

Yaprak örneklerinin toplam Fe kapsamları Mills ve Jones (1996) tarafından belirlenen sınır değerlerine göre karşılaştırılmış olup, yaprak örneklerinin \%10'u noksan, kalanı ise yeterli ve yüksek sınıflarına girmiştir. Yaprak örneklerinin toplam Fe kapsamlarının $62.2-535.4 \mathrm{mg} \mathrm{kg}^{-1}$ arasında değiştiği belirlenmiştir (Çizelge 1). Adıman (2013) Tokat'ta ceviz yapraklarında ölçülen $\mathrm{Fe}$ konsantrasyonunun 43.4-501.4 $\mathrm{mg} \mathrm{kg}^{-1}$ arasında değiştiğini ve ortalama Fe konsantrasyonunun ise $83.0 \mathrm{mg} \mathrm{kg}^{-1}$ olduğunu bildirmiştir. Yaprak örneklerinin toplam $\mathrm{Zn}$ kapsamlarının yeterli olarak belirlenen $22-25 \mathrm{mg} \mathrm{kg}^{-1}$ sınır değerleri ile karşılaştırıldığında \%90'ının noksan düzeyde $\mathrm{Zn}$ içerdiği ve $\mathrm{Zn}$ kapsamlarının 4.0-37.8 $\mathrm{mg} \mathrm{kg}^{-1}$ arasında değiştiği belirlenmiştir. Yıldız ve Uygur (2016) Uşak'ta ceviz yapraklarının $\mathrm{Zn}$ içeriğinin 5.0-25.4 mg kg-1 arasında değiştiğini ve Zn'nin örneklerin \%94'ünde noksan olduğunu belirtmişlerdir. Yaprak örneklerinin toplam Mn analizleri sonucunda tamamının yeterli düzeyde $\mathrm{Mn}$ içerdiği ve $\mathrm{Mn}$ kapsamlarının 40.6-288.6 mg kg-1 arasında değiştiği görülmüştür. Yildız ve Uygur (2016) Uşak'ta ceviz yapraklarının Mn içeriğinin 32.4 ile $293.0 \mathrm{mg} \mathrm{kg}^{-1}$ arasında değiştiğini belirtmişlerdir. Yaprak örneklerinin toplam $\mathrm{Cu}$ analiz sonuçları sınır değerlerine göre \%60'ının yeterli ve yüksek, \%40'ının ise noksan olduğu görülmüştür. Yaprak
Çizelge 1. Yaprak örneklerinin minimum, maksimum ve ortalama değerleri.

Table 1. Minimum, maximum and average values of leaf samples.

\begin{tabular}{lccc}
\hline Besin Elementi & Minimum & Maksimum & Ortalama \\
\hline $\mathrm{N}(\%)$ & 2.19 & 3.18 & 2.58 \\
$\mathrm{P}(\%)$ & 0.13 & 0.19 & 0.16 \\
$\mathrm{~K}(\%)$ & 1.10 & 2.74 & 1.79 \\
$\mathrm{Ca}(\%)$ & 2.01 & 3.91 & 3.05 \\
$\mathrm{Mg}(\%)$ & 0.41 & 0.97 & 0.61 \\
$\mathrm{Fe}\left(\mathrm{mg} \mathrm{kg}^{-1}\right)$ & 62.2 & 535.40 & 137.10 \\
$\mathrm{Zn}\left(\mathrm{mg} \mathrm{kg}^{-1}\right)$ & 4.00 & 37.80 & 12.50 \\
$\mathrm{Mn}\left(\mathrm{mg} \mathrm{kg}^{-1}\right)$ & 40.6 & 288.60 & 138.60 \\
$\mathrm{Cu}\left(\mathrm{mg} \mathrm{kg}^{-1}\right)$ & 2.00 & 48.40 & 8.70 \\
\hline
\end{tabular}

Çizelge 2. Burdur ili ceviz bahçelerinden alınan yaprak örneklerinin sınır değerlerine göre sınıflandırılması.

Table 2. Classification of leaf samples taken from walnut orchards of Burdur province according to the threshold values.

\begin{tabular}{|c|c|c|c|c|}
\hline Element & Değe & endirme & Örnek & $\%$ \\
\hline \multirow{3}{*}{$\begin{array}{l}\mathrm{N}(\%) \\
\text { (Jones ve ark. 1991) }\end{array}$} & Noksan & $2.01-2.49$ & 11 & 55 \\
\hline & Yeterli & $2.50-3.25$ & 9 & 45 \\
\hline & Yüksek & $>3.25$ & - & - \\
\hline \multirow{3}{*}{$\begin{array}{l}\mathrm{P}(\%) \\
\text { (Jones ve ark. 1991) }\end{array}$} & Noksan & $0.09-0.11$ & - & - \\
\hline & Yeterli & $0.12-0.30$ & 20 & 30 \\
\hline & Yüksek & $>0.30$ & - & \\
\hline \multirow{3}{*}{$\begin{array}{l}\text { K }(\%) \\
\text { (Jones ve ark. 1991) }\end{array}$} & Noksan & $0.90-1.19$ & 1 & 5 \\
\hline & Yeterli & $1.20-3.00$ & 19 & 95 \\
\hline & Yüksek & $>3.00$ & - & - \\
\hline \multirow{2}{*}{$\begin{array}{l}\mathrm{Ca}(\%) \\
(\text { Jones ve ark. 1991) }\end{array}$} & Noksan & $<1.0$ & - & - \\
\hline & Yeterli & $>1.0$ & 20 & 100 \\
\hline \multirow{3}{*}{$\begin{array}{l}\operatorname{Mg}(\%) \\
(\text { Jones ve ark. 1991) }\end{array}$} & Noksan & $<0.30$ & - & - \\
\hline & Yeterli & $0.30-1.0$ & 20 & 100 \\
\hline & Yüksek & $>1.0$ & - & - \\
\hline \multirow{3}{*}{$\begin{array}{l}\mathrm{Fe}\left(\mathrm{mg} \mathrm{kg}^{-1}\right) \\
\text { (Mills ve Jones } \\
\text { 1996) }\end{array}$} & Noksan & $<69$ & 2 & 10 \\
\hline & Yeterli & $69-129$ & 11 & 55 \\
\hline & Yüksek & $>129$ & 7 & 35 \\
\hline \multirow{3}{*}{$\begin{array}{l}\mathrm{Zn}\left(\mathrm{mg} \mathrm{kg}^{-1}\right) \\
(\text { Jones ve ark. 1991) }\end{array}$} & Noksan & $<22$ & 18 & 90 \\
\hline & Yeterli & $22-25$ & 5 & 5 \\
\hline & Yüksek & $>25$ & 1 & 5 \\
\hline \multirow{3}{*}{$\begin{array}{l}\operatorname{Mn}\left(\mathrm{mg} \mathrm{kg}^{-1}\right) \\
(\text { Jones ve ark. 1991) }\end{array}$} & Noksan & $<30$ & - & - \\
\hline & Yeterli & $30-300$ & 20 & 100 \\
\hline & Yüksek & $>300$ & - & - \\
\hline \multirow{3}{*}{$\begin{array}{l}\mathrm{Cu}\left(\mathrm{mg} \mathrm{kg}^{-1}\right) \\
(\text { Jones ve ark. 1991) }\end{array}$} & Noksan & $<4.0$ & 8 & 40 \\
\hline & Yeterli & $4.0-20.0$ & 9 & 45 \\
\hline & Yüksek & $>20.0$ & 3 & 15 \\
\hline
\end{tabular}

örneklerinin toplam $\mathrm{Cu}$ kapsamlarının 2.0-48.4 mg kg-1 arasında değiştiği görülmüştür (Çizelge 1, 2). Yıldız ve Uygur (2016) Uşak'ta ceviz yapraklarının $\mathrm{Cu}$ içeriğinin $1.7-15.2 \mathrm{mg} \mathrm{kg}^{-1}$ arasında değiştiğini ve Cu'nun yaprak örneklerinin \%94'ünde noksan olduğunu belirtmişlerdir. Mikro element içeriklerindeki olası noksanlıkların toprak kireç kapsamlarının yüksekliğine bağlı olabileceği ve bu unsurun olumsuz etkilerinin mikro elementler üzerine etkili olabileceği düşünülmektedir.

\subsection{Toprak analiz sonuçları}

Burdur yöresinde ceviz yetiştirilen 20 adet bahçeden 0-30 $\mathrm{cm}$ ve $30-60 \mathrm{~cm}$ toprak derinliklerinden alınan toprak 
örneklerinin analiz sonuçlarına göre minimum, maksimum ve ortalama değerleri Çizelge 3'de verilmiştir. Ayrıca farklı iki derinlikteki toprak örneklerinin bazı analiz sonuçları ilgili literatürlerdeki sınır değerlerine göre sınıflandırılarak Çizelge 4'de verilmiştir. İncelenen bahçelerde $0-30 \mathrm{~cm}$ toprak derinliğinden alınan toprakların \%45'inin hafif alkalin, $\% 55$ 'inin nötr reaksiyon, $30-60 \mathrm{~cm}$ toprak derinliğinde ise $\% 55$ 'inin hafif alkalin; \%45'inin nötr reaksiyona sahip oldukları belirlenmiştir. Alınan toprakların $\mathrm{pH}$ değerleri $0-30 \mathrm{~cm}$ toprak derinliğinde 6.58-7.59 aralığında; $30-60 \mathrm{~cm}$ derinlikte ise 6.84-7.64 aralığında değişmiştir. Toprakların bünyeleri her iki toprak derinliğinde de çoğunlukla orta bünyeli olarak belirlenmiştir (Çizelge 4). Bahçe topraklarının $\mathrm{CaCO}_{3}$ kapsamları 0-30 cm toprak derinliğinde $\% 0.82-28.12 ; 30-60 \mathrm{~cm}$ derinlikte ise \%0.82-26.46 aralığında değişim göstermektedir. Evliya (1964)'ya göre yapılan sinıflandırmada tüm örneklerin her iki derinlikte de kireç içeriklerinin benzer özellik gösterdiği ve yaklaşı \% $\%$ 'inden fazlasının kireç bakımından yüksek ve aşırı kireçli sınıflarına dâhil olduğu görülmüştür. Burdur yöresi ceviz bahçelerinin elektriksel iletkenlik (EC) değerleri; 0-30 cm'lik toprak derinliğinde $0.14-0.31 \mathrm{dS} \mathrm{m}^{-1}, 30-60 \mathrm{~cm}^{\prime}$ lik toprak derinliğinde ise $0.11-0.29 \mathrm{dS} \mathrm{m}^{-1}$ olarak belirlenmiştir. Yöre topraklarının tuzluluk seviyesinin risk oluşturabilecek düzeyde olmadıkları görünmektedir (Çizelge 3, 4).

Burdur yöresinde ceviz yetiştirilen bahçe topraklarının organik madde içerikleri $0-30 \mathrm{~cm}$ toprak derinliğinde $\% 0.80-4.95 ; 30-60 \mathrm{~cm}$ derinlikte ise \%0.26-3.47 aralığında değişim göstermektedir. Ceviz bahçelerinin organik madde içerikleri, Thun ve ark. (1955)'ne göre sınıflandırıldığında 0-30 $\mathrm{cm}$ toprak derinliğinde \%35'inin humusça fakir, \%65'inin az humuslu, $30-60 \mathrm{~cm}$ toprak derinliğinden alınan toprak örneklerinin ise $\% 50$ 'sinin humusça fakir, \%50'sinin ise az humuslu sınıfa girdiği tespit edilmiştir. Ceviz bahçelerinden alınan toprakların yaklaşık $\% 50$ 'sinden fazlasının $\% 2$ ve altında organik madde içeriyor olması toprak organik maddesinin yetersiz olduğunu ve organik gübrelemeye ihtiyaç olduğunu göstermektedir (Çizelge 3, 4).

Burdur yöresindeki ceviz bahçelerinden alınan toprak örneklerinin toplam N değerleri Loue (1968)'ya göre sınıflandırıldığında, 0-30 cm'lik toprak derinliğinde toprakların toplam N kapsamlarının \%85'inin iyi ve çok iyi, 30-60 cm'lik toprak derinliğinde ise \%70'inin iyi ve çok iyi sınıfta yer aldığ tespit edilmiştir. Toprak örneklerinin toplam $\mathrm{N}$ içerikleri $0-30$ cm'lik toprak derinliğinde $\% 0.07-0.27$ ve $30-60 \mathrm{~cm}$ derinlikte ise \%0.08-0.26 değerleri arasında bulunmaktadır. Toprakların toplam $\mathrm{N}$ içeriklerinin yeterliliğinin büyük oranda kimyasal gübrelemenin etkisinden kaynaklanabileceği düşünülmektedir. Ceviz bahçeleri toprak örneklerinin alınabilir P kapsamları; 0-30 cm derinlikte $2.36-21.30 \mathrm{mg} \mathrm{kg}^{-1}, 30-60 \mathrm{~cm}$ derinlikte ise 2.60-21.12 mg kg-1 aralığında değişim göstermiştir. Çizelge 4'de de görüldüğü üzere toprakların alınabilir $\mathrm{P}$ kapsamları Olsen ve Sommers (1982)'in verdiği sınır değerlerine göre sınıflandırılmış olup 0-30 cm derinlikte yaklaşık \%75'i, 30-60 $\mathrm{cm}$ derinlikte ise $\% 45$ 'i orta ve yüksek düzeylerde alınabilir $\mathrm{P}$ içermektedir. Topraklardaki kireç kapsamlarının, toprakların $\mathrm{pH}$ düzeylerinin ve uygulanan fosforlu gübre miktarlarının toprakların fosfor düzeyleri üzerine etkilerinin bulunduğu bilinmektedir. Toprakların her iki toprak derinliğinde de P bakımından yeterlilikleri istenilen düzeylerde olmayıp ilave uygulamalara (gübreleme) ihtiyaç söz konusudur.

Burdur yöresindeki ceviz bahçelerinin toprak örneklerinin bitkiye yarayışlı K kapsamları; 0-30 cm derinlikte 77.2-617.8 $\mathrm{mg} \mathrm{kg}{ }^{-1}$ ve $30-60 \mathrm{~cm}$ derinlikte ise $115.8-678.6 \mathrm{mg} \mathrm{kg}^{-1}$ değer aralığında değiştiği gözlenmiştir. Toprakların bitkiye yarayışlı K kapsamları FAO (1990)'a göre sinıflandırıldığında, 0-30 cm ve $30-60 \mathrm{~cm}$ toprak derinliklerinde $\% 75$ 'inin yeterli ve fazla sınıfları arasında yer aldığı belirlenmiştir. Her iki derinlikte de yaklaşık \%5-10 düzeyinde $\mathrm{K}$ noksanlığı gözlemlenmiştir. Toprak örneklerinin bitkiye yarayışlı Ca kapsamları FAO (1990)'a göre sınıflandırıldığında, toprak örneklerinin 0-30 cm toprak derinliğine \%90'ının yeterli ve fazla, 30-60 cm toprak derinliğinde \%90'ının yeterli düzeyde bitkiye yarayışlı Ca içerdiği görülmektedir (Çizelge 4). Toprak örneklerinin bitkiye yarayışlı Ca kapsamları; 0-30 cm derinlikte 815.8-3523.0 $\mathrm{mg} \mathrm{kg}^{-1}$ ve $30-60 \mathrm{~cm}$ derinlikte $506.8-2928.0 \mathrm{mg} \mathrm{kg}^{-1}$ değerleri aralığında değişmektedir. Toprakların yüksek kireç kapsamlarının bitkiye yarayışlı $\mathrm{Ca}$ içeriklerinin yeterli ve yüksek olmasına neden olabileceği düşünülmektedir. Kurak yarı kurak bölge topraklarında toprak oluşumunda kalsifikasyon sürecinin etkin olması (Atalay 2005) hem iyon değiştiricilerin yüzeyinde hem de ayrı biz faz olarak karbonatların birikmesine neden olduğundan toprakların yarayışlı (suda çözünebilir + değişebilir) $\mathrm{Ca}$ içeriklerinin yeterli/yüksek olduğu değerlendirilmiştir. Alınan toprak örneklerinin bitkiye yarayışlı Mg analiz sonuçları, FAO (1990)'a göre sinıflandırıldığında; toprakların $0-30 \mathrm{~cm}$ derinliğinde yaklaşı \% $\%$ 'inin yeterli ve fazla, 30-60 cm derinlikte \%60'ının yeterli ve fazla düzeyde

Çizelge 3. Toprak örnekleri analiz sonuçlarının minimum, maksimum ve ortalama değerleri.

Table 3. Minimum, maximum and average values of soil samples analysis results.

\begin{tabular}{|c|c|c|c|c|c|c|}
\hline \multirow{2}{*}{ Toprak Özelliği } & \multicolumn{3}{|c|}{$0-30 \mathrm{~cm}$} & \multicolumn{3}{|c|}{$30-60 \mathrm{~cm}$} \\
\hline & Minimum & Maksimum & Ortalama & Minimum & Maksimum & Ortalama \\
\hline $\mathrm{pH}$ & 6.58 & 7.59 & 7.32 & 6.84 & 7.64 & 7.36 \\
\hline $\mathrm{CaCO}_{3}(\%)$ & 0.82 & 28.12 & 12.08 & 0.82 & 26.46 & 11.69 \\
\hline $\mathrm{EC}\left(\mathrm{dS} \mathrm{m} \mathrm{m}^{-1}\right)$ & 0.14 & 0.31 & 0.20 & 0.11 & 0.29 & 0.19 \\
\hline Organik Madde $(\%)$ & 0.80 & 4.95 & 2.34 & 0.26 & 3.47 & 1.78 \\
\hline Toplam N (\%) & 0.07 & 0.27 & 0.17 & 0.08 & 0.26 & 0.16 \\
\hline Alınabilir $\mathrm{P}\left(\mathrm{mg} \mathrm{kg}^{-1}\right)$ & 2.36 & 21.30 & 8.71 & 2.60 & 21.12 & 7.76 \\
\hline Yarayışlı $\mathrm{K}\left(\mathrm{mg} \mathrm{kg}^{-1}\right)$ & 77.20 & 617.80 & 233.80 & 115.80 & 678.60 & 261.80 \\
\hline Yarayışlı Ca $\left(\mathrm{mg} \mathrm{kg}^{-1}\right)$ & 815.80 & 3523.00 & 2693.00 & 506.80 & 2928.00 & 2094.80 \\
\hline Yarayışlı $\mathrm{Mg}\left(\mathrm{mg} \mathrm{kg}^{-1}\right)$ & 80.20 & 508.60 & 257.90 & 74.00 & 569.00 & 238.50 \\
\hline DTPA-Fe $\left(\mathrm{mg} \mathrm{kg}^{-1}\right)$ & 0.60 & 4.55 & 1.78 & 0.65 & 10.07 & 2.64 \\
\hline DTPA-Zn $\left(\mathrm{mg} \mathrm{kg}^{-1}\right)$ & 0.14 & 2.71 & 1.20 & 0.03 & 2.73 & 0.88 \\
\hline DTPA-Mn $\left(\mathrm{mg} \mathrm{kg}^{-1}\right)$ & 4.12 & 15.21 & 7.51 & 3.23 & 14.54 & 6.39 \\
\hline DTPA-Cu $\left(\mathrm{mg} \mathrm{kg}^{-1}\right)$ & 0.92 & 10.68 & 3.64 & 1.17 & 7.44 & 3.22 \\
\hline
\end{tabular}


Çizelge 4. Burdur yöresinde ceviz bahçelerinden alınan toprak örneklerinin sınır değerlerine göre sınıflandırılması.

Table 4. Classification of soil samples taken from walnut orchards in Burdur region according to the threshold values.

\begin{tabular}{|c|c|c|c|c|c|c|c|c|}
\hline \multirow[b]{3}{*}{ Toprak Özelliği } & \multirow[b]{3}{*}{ Sinır Değerleri } & \multirow[b]{3}{*}{ Değerlendirme } & \multicolumn{4}{|c|}{ Derinlik } & \multirow{2}{*}{\multicolumn{2}{|c|}{ Toplam }} \\
\hline & & & \multicolumn{2}{|c|}{$0-30 \mathrm{~cm}$} & \multicolumn{2}{|c|}{$30-60 \mathrm{~cm}$} & & \\
\hline & & & Örnek Sayısı & $(\%)$ & Örnek Sayısı & $(\%)$ & Örnek Sayısı & $(\%)$ \\
\hline $\mathrm{pH}$ & $6.6-7.3$ & Nötr & 11 & 55 & 9 & 45 & 11 & 27.5 \\
\hline Kellog (1952) & 7.4-7.8 & Hafif Alkalin & 9 & 45 & 11 & 55 & 29 & 72.5 \\
\hline \multirow{5}{*}{$\begin{array}{l}\mathrm{CaCO}_{3}(\%) \\
\text { Evliya (1964) }\end{array}$} & $0-2.5$ & Düşük & 3 & 15 & 4 & 20 & 7 & 17.5 \\
\hline & $2.5-5.0$ & Kireçli & 5 & 25 & 3 & 15 & 8 & 20 \\
\hline & $5.1-10.0$ & Yüksek & 3 & 15 & 5 & 25 & 8 & 20 \\
\hline & $10.1-20.0$ & Çok Yüksek & 2 & 10 & 1 & 5 & 3 & 7.5 \\
\hline & $20.1<$ & Aşırı Kireçli & 7 & 35 & 7 & 35 & 14 & 35 \\
\hline $\begin{array}{l}\text { EC }\left(\mathrm{dS} \mathrm{m} \mathrm{m}^{-1}\right) \\
\text { Soil Survey Staff (1951) }\end{array}$ & $2.5>$ & Tuzsuz & 20 & 100 & 20 & 100 & 40 & 100 \\
\hline Organik Madde $(\%)$ & $0-2$ & Humusça Fakir & 7 & 35 & 10 & 50 & 17 & 42.5 \\
\hline Thun ve ark. (1955) & $2-5$ & Az Humuslu & 13 & 65 & 10 & 50 & 23 & 57.5 \\
\hline \multirow{9}{*}{$\begin{array}{l}\text { Bünye } \\
\text { (Bouyoucos 1952) }\end{array}$} & Tin & & 8 & 40 & 7 & 35 & 15 & 37.5 \\
\hline & Kumlu Tin & & 4 & 20 & 3 & 15 & 7 & 17.5 \\
\hline & Kumlu Killi Tin & & 1 & 5 & 4 & 20 & 5 & 12.5 \\
\hline & Kumlu Kil & & 1 & 5 & - & - & 1 & 2.5 \\
\hline & Siltli Killi Tın & & 2 & 10 & 2 & 10 & 4 & 10.0 \\
\hline & Siltli Tın & & 3 & 15 & - & - & 3 & 7.5 \\
\hline & Killi Tın & & 1 & 5 & 2 & 10 & 3 & 7.5 \\
\hline & Silt & & - & - & 1 & 5 & 1 & 2.5 \\
\hline & Kil & & - & - & 1 & 5 & 1 & 2.5 \\
\hline \multirow{4}{*}{$\begin{array}{l}\text { Toplam N (\%) } \\
\text { Loue (1968) }\end{array}$} & $0.070-0.090$ & Fakir & 3 & 15 & 3 & 15 & 6 & 15 \\
\hline & $0.091-0.110$ & Orta & - & - & 3 & 15 & 3 & 7.5 \\
\hline & $0.111-0.130$ & İyi & 2 & 10 & 1 & 5 & 3 & 7.5 \\
\hline & $0.131<$ & Çok İyi & 15 & 75 & 13 & 65 & 28 & 70 \\
\hline \multirow{3}{*}{$\begin{array}{l}\left.\text { Alınabilir P (mg kg }{ }^{-1}\right) \\
\text { Olsen ve Sommers (1982) }\end{array}$} & $5<$ & Düşük & 5 & 25 & 11 & 55 & 16 & 40 \\
\hline & $5-10$ & Orta & 9 & 45 & 4 & 20 & 13 & 32.5 \\
\hline & $10>$ & Yüksek & 6 & 30 & 5 & 25 & 11 & 27.5 \\
\hline \multirow{4}{*}{$\begin{array}{l}\mathrm{K}\left(\mathrm{mg} \mathrm{kg}^{-1}\right) \\
\text { FAO }(1990)\end{array}$} & $<50$ & Çok Az & - & - & - & - & - & - \\
\hline & $50-140$ & $\mathrm{Az}$ & 5 & 25 & 5 & 25 & 10 & 25 \\
\hline & $140-370$ & Yeterli & 12 & 60 & 12 & 60 & 24 & 60 \\
\hline & $370-1000$ & Fazla & 3 & 15 & 3 & 15 & 6 & 15 \\
\hline \multirow{4}{*}{$\begin{array}{l}\mathrm{Ca}\left(\mathrm{mg} \mathrm{kg}^{-1}\right) \\
\text { FAO }(1990)\end{array}$} & $0-380$ & Çok Az & - & - & - & - & - & - \\
\hline & $380-1150$ & $\mathrm{Az}$ & 2 & 10 & 4 & 10 & 6 & 15 \\
\hline & $1150-3500$ & Yeterli & 17 & 85 & 16 & 90 & 33 & 82.5 \\
\hline & $3500-10000$ & Fazla & 1 & 5 & - & - & 1 & 2.5 \\
\hline \multirow{4}{*}{$\begin{array}{l}\operatorname{Mg}\left(\mathrm{mg} \mathrm{kg}^{-1}\right) \\
\text { FAO }(1990)\end{array}$} & $0-50$ & Çok Az & 0 & 0 & 0 & 0 & 0 & 0 \\
\hline & $50-160$ & $\mathrm{Az}$ & 6 & 30 & 8 & 40 & 14 & 35 \\
\hline & $160-480$ & Yeterli & 13 & 65 & 9 & 45 & 22 & 55 \\
\hline & $480-1500$ & Fazla & 1 & 5 & 3 & 15 & 4 & 10 \\
\hline \multirow{3}{*}{$\begin{array}{l}\text { DTPA-Fe } \\
\left(\mathrm{mg} \mathrm{kg}^{-1}\right) \\
\text { Lindsay ve Norvell (1978) }\end{array}$} & $2.5>$ & Noksan & 18 & 90 & 16 & 80 & 34 & 85 \\
\hline & $2.5-4.5$ & Noksanlik & 1 & 5 & 1 & 5 & 2 & 5 \\
\hline & $4.5<$ & $\begin{array}{l}\text { Gösterebilir } \\
\text { İyi }\end{array}$ & 1 & 5 & 3 & 15 & 4 & 10 \\
\hline \multirow{3}{*}{$\begin{array}{l}\text { DTPA-Zn } \\
\left(\mathrm{mg} \mathrm{kg}^{-1}\right) \\
\text { Lindsay ve Norvell (1978) }\end{array}$} & $0.5>$ & Noksan & 4 & 20 & 9 & 45 & 13 & 32.5 \\
\hline & $0.5-1.0$ & Noksanlik & 6 & 30 & 3 & 15 & 9 & 22.5 \\
\hline & $1.0<$ & $\begin{array}{l}\text { Gösterebilir } \\
\text { İyi }\end{array}$ & 10 & 50 & 8 & 40 & 18 & 45 \\
\hline $\begin{array}{l}\text { DTPA-Mn }\left(\mathrm{mg} \mathrm{kg}^{-1}\right) \\
\text { Lindsay ve Norvell (1978) }\end{array}$ & $1<$ & Yeterli & 20 & 100 & 20 & 100 & 40 & 100 \\
\hline $\begin{array}{l}\text { DTPA-Cu (mg kg-1) } \\
\text { Lindsay ve Norvell (1978) }\end{array}$ & $0.2<$ & Yeterli & 20 & 100 & 20 & 100 & 40 & 100 \\
\hline
\end{tabular}

bitkiye yarayışlı Mg içerdiği belirlenmiștir (Çizelge 4). Toprak örneklerinin bitkiye yarayışlı $\mathrm{Mg}$ kapsamları; 0-30 cm derinlikte 80.2-508.6 mg kg-1,30-60 cm derinlikte 74.0-569.0 mg kg-1 aralığında değiştiği görülmektedir (Çizelge 3). Adıman (2013) tarafından ceviz bahçelerinde yürütülen bir araştırmada toprakların bitkiye yarayışlı $\mathrm{K}, \mathrm{Ca}$ ve $\mathrm{Mg}$ içeriklerinin yeterli ve yüksek düzeylerde olduğu bildirilmiştir. 
Burdur yöresindeki ceviz bahçelerinin toprak örneklerinin alınabilir $\mathrm{Fe}$ analiz sonuçları, $0-30 \mathrm{~cm}$ derinlikte 0.60-4.55 $\mathrm{mg} \mathrm{kg}^{-1}$ ve $30-60 \mathrm{~cm}$ derinlikte $0.65-10.07 \mathrm{mg} \mathrm{kg}^{-1}$ değerleri arasında değiştiği görülmektedir (Çizelge 3). Lindsay ve Norvell (1978)'e göre sınıflandırılmış ve toprak örneklerinin alınabilir Fe içeriklerinin 0-30 cm derinlikte \%95'inin, 30-60 $\mathrm{cm}$ derinlikte ise \%85'inin noksanlı düzeylerinde olduğu belirlenmiştir (Çizelge 4). Ceviz bahçelerinin topraklarının büyük çoğunluğunun hafif alkalin özellik taşıması, ayrıca yüksek kireç kapsamından dolayı topraktaki demirin hızlı bir şekilde bitkiler tarafindan alınabilirliğinin azalması veya tamamen alınamaz hale dönüşebileceği araştırıcılar tarafından bildirilmiştir (Kacar ve Katkat 2007). Yıldız ve Uygur (2016) yaptıkları çalışmada ceviz bahçelerinde toprakların \%78'inde Fe noksanlığının söz konusu olduğunu bildirmişlerdir.

Toprakların alınabilir $\mathrm{Zn}$ içeriklerinin her iki derinlikte de $\% 50$ 'den fazlası noksanlık düzeylerinde olduğu (Çizelge 3), $0-30 \mathrm{~cm}$ derinlikte $0.14-2.71 \mathrm{mg} \mathrm{kg}^{-1}$ ve $30-60 \mathrm{~cm}$ derinlikte $0.03-2.73 \mathrm{mg} \mathrm{kg}^{-1}$ aralığında değiştiği görülmektedir (Çizelge 4). Toprakların alınabilir $\mathrm{Mn}$ ve $\mathrm{Cu}$ içeriklerinin her iki derinlikte de yeterli olduğu belirlenmiştir. Toprakların alınabilir Mn içeriklerinin 0-30 cm derinlikte 4.12-15.21 mg kg-1, 30-60 $\mathrm{cm}$ derinlikte ise $3.23-14.54 \mathrm{mg} \mathrm{kg} \mathrm{kg}^{-1}$ aralığında olduğu, alınabilir $\mathrm{Cu}$ içeriklerinin 0-30 cm derinlikte $0.92-10.68 \mathrm{mg} \mathrm{kg}^{-1}$ ve $30-60 \mathrm{~cm}$ derinlikte ise $1.17-7.44 \mathrm{mg} \mathrm{kg}^{-1}$ aralığında değişim gösterdiği belirlenmiştir (Çizelge 3). Adıman (2013) tarafından ceviz bahçelerinde yapılan araştırmada da toprakların alınabilir $\mathrm{Zn}$ içeriklerinin noksan, $\mathrm{Cu}$ ve $\mathrm{Mn}$ ise içeriklerinin yeterli olduğu bildirilmiştir.

Burdur yöresinde yapılan araştırmada ceviz yaprak örneklerinin besin elementi içerikleri ile toprak örneklerinin bazı kimyasal ve fiziksel özellikleri arasındaki ilişkiler belirlenerek Çizelge 5'de verilmiştir. Yaprak örneklerinin toplam $\mathrm{N}$ içerikleri ile 0-30 cm'den alınan toprak örneklerinin kireç içeriklerinde \%5 düzeyinde pozitif $\left(\mathrm{r}=455^{*}\right)$ ve toplam $\mathrm{Mg}$ içerikleri ile 30-60 $\mathrm{cm}$ derinlikten alınan toprak örneklerinin alınabilir $\mathrm{Cu}$ içerikleri arasında $\% 1$ düzeyinde pozitif $\left(\mathrm{r}=639^{* *}\right)$ ilişki belirlenmiştir. Yaprak örneklerinin toplam $\mathrm{K}$ içerikleri ile toprakta $0-30 \mathrm{~cm}$ derinlikte alınabilir $\mathrm{Ca}$ içerikleri arasında $\% 5$ düzeyinde negatif $(\mathrm{r}=0.492 *)$ ilişki belirlenmiştir. $\mathrm{K}, \mathrm{Ca}$ ve $\mathrm{Mg}$ gibi katyonlar arasında antagonistik ilişkiler bulunmaktadır ve bu antagonizm besin elementlerinin alınabilirlikleri üzerinde olumsuz etkilere sahiptir (Jones ve ark. 1991). Besin solüsyonunda herhangi bir katyonik besin elementinin miktarının $\left(\mathrm{NH}_{4}{ }^{+}, \mathrm{Ca}^{2+}, \mathrm{Mg}^{2+}, \mathrm{K}^{+}\right.$, $\mathrm{Na}^{+}$) artmasının bitki dokusundaki diğer katyonların miktarında azalmaya neden olduğu, bu durumun da besin iyonlarının aynı tutunma bölgeleri için girdikleri rekabetten kaynaklandığ 1 ifade edilmektedir (Korkmaz ve Saltalı 2012). Yaprak örneklerinin toplam Fe içerikleri ile 0-30 cm'den alınan toprak örneklerinin $\mathrm{pH}$ değerleri arasında \%1 düzeyinde negatif ilişki $(\mathrm{r}=-660 * *)$, 30-60 cm'den alınan toprak örneklerinin $\mathrm{pH}$ değerleri arasında $\% 5$ düzeyinde negatif ilişki $\left(r=-508^{*}\right)$ ve $30-60$ $\mathrm{cm}$ 'den alınan toprak örneklerinin $\mathrm{Fe}$ içerikleri arasında $\% 5$ düzeyinde pozitif $\left(r=0.529^{*}\right)$ ilişki belirlenmiştir. Toprak pH'sının bitkilerin Fe içeriklerini azaltıcı etkileri bilinmektedir (Turan ve Horuz 2012; Bloom ve Inskeep 1988).

Yaprak örneklerinin toplam Zn içerikleri ile 30-60 cm'den alınan toprak örneklerinin Fe içerikleri arasında \%1 düzeyinde pozitif ilişki $\left(\mathrm{r}=0.620^{* *}\right)$ ve $0-30 \mathrm{~cm}$ 'den alınan toprak örneklerinin $\mathrm{pH}$ değerleri arasında $\% 5$ düzeyinde negatif $\left(\mathrm{r}=-0.493^{*}\right)$ ilişki belirlenmiştir. Topraktaki demirin absorpsiyonu üzerine diğer katyonların $\left(\mathrm{Mn}^{2+}, \mathrm{Cu}^{2+}, \mathrm{Ca}^{2+}, \mathrm{Mg}^{2+}\right.$, $\mathrm{K}^{+}$ve $\mathrm{Zn}^{2+}$ ) önemli etkileri vardır (Turan ve Horuz 2012; Aktaş 1991). Artan toprak pH's1 toprak çözeltisindeki Zn
Çizelge 5. Ceviz yaprak örneklerinin besin elementleri içerikleri ile toprak örneklerinin fiziksel ve kimyasal özellikleri arasındaki önemli ilişkiler.

Table 5. Significant relationships between nutrient content of walnut leaf samples and physical and chemical properties of soil samples.

\begin{tabular}{|c|c|c|c|}
\hline $\begin{array}{l}\text { Bitki } \\
(\mathrm{X})\end{array}$ & $\begin{array}{l}\text { Toprak } \\
\text { (Y) }\end{array}$ & $\begin{array}{c}\text { Korelâsyon } \\
\text { Katsayısı (Pearson r) }\end{array}$ & Regresyon eşitliği \\
\hline $\mathrm{N}$ & 0-30 Kireç & $0.455^{*}$ & $\mathrm{X}=2.39+0.0162 \mathrm{Y}$ \\
\hline $\mathrm{K}$ & $0-30 \mathrm{Ca}$ & $-0.492 *$ & $\mathrm{X}=2.50-0.0526 \mathrm{Y}$ \\
\hline $\mathrm{Mg}$ & $30-60 \mathrm{Cu}$ & $0.639 * *$ & $\mathrm{X}=0.458+0.0458 \mathrm{Y}$ \\
\hline \multirow{3}{*}{$\mathrm{Fe}$} & $0-30 \mathrm{pH}$ & $-0.660 * *$ & $X=2322-298 \mathrm{Y}$ \\
\hline & $30-60 \mathrm{pH}$ & $-0.508^{*}$ & $\mathrm{X}=2022-256 \mathrm{Y}$ \\
\hline & $30-60 \mathrm{Fe}$ & $0.529^{*}$ & $\mathrm{X}=82.5+20.7 \mathrm{Y}$ \\
\hline \multirow{2}{*}{$\mathrm{Zn}$} & $30-60 \mathrm{Fe}$ & $0.620 * *$ & $X=8.04+1.69 Y$ \\
\hline & $0-30 \mathrm{pH}$ & $-0.493 *$ & $\mathrm{X}=127-15.6 \mathrm{Y}$ \\
\hline \multirow{2}{*}{ Mn } & $0-30 \mathrm{pH}$ & $-0.512 *$ & $X=1380-169 Y$ \\
\hline & $30-60 \mathrm{pH}$ & $-0.553 * *$ & $X=1643-204 Y$ \\
\hline \multirow{3}{*}{$\mathrm{Cu}$} & $0-30 \mathrm{~K}$ & $0.669 * *$ & $X=-3.10+19.7 Y$ \\
\hline & $0-30 \mathrm{Cu}$ & $0.807 * * *$ & $\mathrm{X}=-4.06+3.50 \mathrm{Y}$ \\
\hline & $30-60 \mathrm{Cu}$ & $0.528 *$ & $\mathrm{X}=0.11+2.67 \mathrm{Y}$ \\
\hline
\end{tabular}

konsantrasyonunu azaltır, çözünürlüğü güç çinkolu bileşikler (Çinko Hidroksitler, Çinko Karbonatlar) oluşur ve dolayısıyla bitkide $\mathrm{Zn}$ düzeyleri de azalmaya başlar (Mengel ve Kirkby 2001; Moraghan ve Mascagni 1991).

Yaprak örneklerinin toplam Mn içerikleri ile 0-30 cm'den alınan toprak örneklerinin $\mathrm{pH}$ değerleri arasında $\% 5$ düzeyinde negatif $(\mathrm{r}=-0.512 *)$ ve $30-60 \mathrm{~cm}$ 'den alınan toprak örneklerinin $\mathrm{pH}$ değerleri arasında $\% 1$ düzeyinde negatif $(\mathrm{r}=0.553 * *)$ ilişki belirlenmiştir. Gereğinden fazla kireçlemenin ve toprak pH'sının yükselmesi bitkilerin $\mathrm{Mn}$ alımını olumsuz etkilemektedir (Parker ve Walker 1986). Yaprak örneklerinin toplam $\mathrm{Cu}$ içerikleri ile 0-30 cm'den alınan toprak örneklerinin alınabilir $\mathrm{K}$ içeriklerinde $\% 1$ düzeyinde pozitif $\left(\mathrm{r}=0.669^{* *}\right), \mathrm{Cu}$ içeriklerinde $\% 0.1$ düzeyinde pozitif $(\mathrm{r}=0.807 * * *)$ ve $30-60 \mathrm{~cm}$ toprak derinliğindeki $\mathrm{Cu}$ içeriğinde $\% 5$ düzeyinde pozitif $(\mathrm{r}=$ $0.528 *$ ) ilişkiler belirlenmiştir. Temel gübrelemede kullanılan ve $\mathrm{N}, \mathrm{P}, \mathrm{K}$ içeren gübrelerin yüksek miktarda kullanımının, bitkilerde $\mathrm{Cu}$ yarayışlılığı üzerine olumsuz etkileri olmaktadır. Toprak çözeltisindeki Fe, $\mathrm{Zn}$ ve Mn'ın yüksek miktarlarda bulunması, bitkilerin $\mathrm{Cu}$ alınımına antagonistik etkide bulunmaktadır (Halder ve Mandal 1979).

\section{Sonuç}

Burdur yöresinde ceviz yetiştirilen bahçelerden alınan yaprak örneklerinin besin elementi konsantrasyonlarının N, P, $\mathrm{Zn}$ ve $\mathrm{Cu}$ konsantrasyonları noksan olarak belirlenirken diğer besin elementleri bakımından yeterli olduğu belirlenmiştir. $\mathrm{Bu}$ durumun oluşmasında toprak özelliklerinin önemli etkileri olduğu görülmektedir. Özellikle toprak organik maddesindeki yetersizlik ve toprak kireç kapsamındaki yükseklik temel sorun olarak belirtilebilir. Yöre bahçelerinde bitki besleme ve gübreleme uygulamalarının mevcut koşullar dikkate alınarak sürdürülmesi bitki sağlığı ve verimlilik bakımından oldukça önemlidir.

Verim ve ürün kalitesi dikkate alındığında yeterli ve dengeli gübreleme büyük öneme sahiptir. Burdur yöresi ceviz yetiştiriciliğinde sürdürülebilirliğin, verimin ve kalitenin artırılabilmesi planlı ve yeterli-dengeli besleme pratiklerinin uygulanmasına ihtiyaç söz konusudur. Bu amaçla toprakların 
organik madde kapsamlarının iyileştirilmesine yönelik uygulamaların yapılması gerekmektedir. En ekonomik yöntem ise yörede faaliyet gösteren hayvan işletmelerinden sağlanabilecek olan çiftlik gübreleri ve tavuk gübreleridir. Ceviz bahçelerinde verim ve kaliteye etki eden temel elementlerden $\mathrm{N}$, $\mathrm{P}, \mathrm{K}$ gibi makro elementlerle $\mathrm{Fe}, \mathrm{Cu}, \mathrm{Zn}$ gibi mikro elementlerin noksan olması kompoze ve mikro element içerikli gübreler kullanılarak giderilebilir. Gübreleme yapmadan önce toprak analizlerine göre planlama yapmalı ve çeşit özelliklerinin de gübrelemede dikkate alınması önemlidir.

\section{Kaynaklar}

Adıman M (2013) Tokat ili Niksar ilçesi ceviz bahçelerinin mineral beslenme durumlarının belirlenmesi. Yüksek Lisans Tezi, Gaziosmanpaşa Üniversitesi, Fen Bilimleri Enstitüsü, Tokat.

Akça Y (2012) Ceviz Yetiştiriciliği. Anıt Matbaası, Ankara.

Aktaş M (1991). Bitki Besleme ve Toprak Verimliliği. Ankara Üniversitesi Ziraat Fakültesi Yayınları:1202, Ankara.

Arslan R (2012) Yaprak analizi için örneklerin alınması. https://arastirma.tarimorman.gov.tr/alata/Belgeler/brosurler/Yaprak ornegiAlinmasi4.pdf. Erişim 24 Aralık 2019.

Atalay İ (2005) Kuvaterner'deki iklim değişmelerinin Türkiye doğal ortamı üzerindeki etkileri. Türkiye Kuvaterner Sempozyumu, İstanbul Teknik Üniversitesi Avrasya Yer Bilimleri Enstitüsü, İstanbul, s. 121-128.

Başaran M (2005) Çankırı (Kentbağ) orman fidanlığı topraklarının bazı fiziksel ve kimyasal özelliklerinin fidanların beslenme durumları üzerine etkisi. Harran Üniversitesi Ziraat Fakültesi Dergisi 9(1): 2330.

Black CA (1965) Methods of Soil Analysis Part 2, Madisson, Wilconsin, USA.

Bloom PR, Inskeep WP (1988) Factors effecting bicarbonate chemistry and iron clorosis in soils. Journal of Plant Nutrition 9: 215-228.

Bouyoucos GJ (1951) A recalibration of the hydrometer method for making mechanical analysis of the soils. Agronomy Journal 4(9): 434.

Chapman HD, Pratt PF, Parker F (1961) Methods of Analysis for Soils, Plants and Waters. University of California Divison of Agricultural Science, Riverside.

Çağlar KÖ (1949) Toprak Bilgisi. Ankara Üniversitesi Ziraat Fakültesi Yayınları, Ankara.

Drossopoulos B, Kouchaji GG, Bouranis DL (1996) Seasonal dynamics of mineral nutrient and carbonhydrates by walnut tree leaves. Journal of Plant Nutrition 19(3\&4): 493-516.

Evliya H (1964) Kültür Bitkilerinin Beslenmesi. Ankara Üniversitesi Ziraat Fakültesi Yayınları, Ankara.

FAO (1990) Micronutrient, Assessment at the Country Level: An international study. FAO Soil Bulletin by Sillanpaa. Rome.

FAO (2017) Production. www.fao.org.tr. Erişim 24 Aralık 2019.

Halder M, Mandal LN (1979). Influence of soil moisture regimes and organic matter application on extractable $\mathrm{Zn}$ and $\mathrm{Cu}$ content in rice soils. Plant and Soil 53: 203-213.

Jackson MC (1967) Soil Chemical Analysis. Prentice Hall of India Private'Limited, New Delhi.

Jackson ML (1959) Soil Chemical Analysis. Englewood Cliffs, New Jersey, USA.

Jones JB, Wolf B, Mills HA (1991) Plant Analysis Handbok. MicroMacro Publishing, USA.

Kacar B (1995) Bitki ve Toprağın Kimyasal Analizleri: III. Toprak Analizleri. Ankara Üniversitesi Ziraat Fakültesi Geliştirme Vakfı Yayınları, Ankara.
Kacar B, Katkat AV (2007) Bitki Besleme. Nobel Yayınları, Ankara.

Kacar B, İnal A (2008) Bitki Analizleri. Nobel Yayınları, Ankara.

Kacar B (2009) Toprak Analizleri. Nobel Yayınları, Ankara.

Kellog CE (1952) Our garden soils. The Macmillan Company, Newyork.

Korkmaz A, Saltalı K (2012) Bitki besin elementi yarayışılılı̆̆ını etkileyen faktörler. Bitki Besleme, Gübretaş Rehber Kitaplar Dizisi, Ankara.

Lindsay WL, Norvell WA (1978) Development of a DTPA soil test for zinc, iron, manganese and copper. Soil Science Society of America Journal 42(3): 421-428.

Loue A (1968) Diagnostic petiolaire de prospection etudes sur la nutrition et la fertilisation potassiques de la vigne. Societe Commerciale des Potasses d' Alsace Services Agronomiques, pp. 31-41.

Mengel K, Kirkby EA (2001) Principles of Plant Nutrition. 5th edition. Kluwer Academic Publishers. Dordrecht, The Nederlands.

Mills HA, Jones JB Jr (1996) Plant Analysis Handbook. II. Micromacro Publishing, Athens, Georgia, USA.

Moraghan JT, Mascagni HJ Jr (1991) Environmental and Soil Factors Effecting Micronutrient Deficiencies and Toxicities. SSSA Book Series, Madison, WI.

Olsen SR, Sommers EL (1982) Phosphorus Availability Indices. Phosphorus soluble in sodium bicarbonate. In: Methods of soil analysis, Part II. Chemical and microbiological properties. ASASSSA, Agronomy Series, No: 9. Madison. Wisconsin, USA, pp. 404-430.

Parker MB, Walker ME (1986) Soil pH and manganese effects on manganese nutrition of peanut. Agronomy Journal 78: 614-620.

Ponder F, Jones JE, Haines J (1998) Annual applications of N, P and K for four years moderately increase nut production in black walnut. HortScience 33(6):1011-1013.

Ponder F (2004) Soils and nutrition management for black walnut in a new century. Proceedings of the $6^{\text {th }}$ Walnut Council Research Symposium, pp: 71-76.

Soil Survey Staff (1951) Soil survey manuel. Agricultural Research Administration, United States Department of Agriculture, Handbook No: 18.

Solmaz Y (2014) Tekirdağ ilinde ceviz bahçeleri beslenme durumlarının yaprak analizleriyle belirlenmesi. Yüksek Lisans Tezi, Namık Kemal Üniversitesi Fen Bilimleri Enstitüsü, Tekirdağ.

Şen SM (2011) Ceviz Yetiştiriciliği-Besin Değeri-Folkloru, ÜÇM Yayıncilık, Ankara.

Thun R, Hermann R, Knickman E (1955) Die untersuchung von boden neuman verlag, Radelbeul und Berlin.

TUIKK (2019) Bitkisel üretim istatistikleri http://www.tuik.gov.tr. Erişim 24 Aralık 2019.

Turan M, Horuz A (2012) Bitki Beslemenin Temel İlkeleri. Bitki Besleme. Gübretaş Rehber Kitaplar Dizisi, Ankara.

Uygur V, Beyazıt S, Çalışkan O (2013) Interrelation between leaf nutrient concentrations and yield and plant morphology of walnut cultivars Juglans regia under subtropics ecology of Turkey. SoilWater Journal 2(2): 821-828.

Yıldız E, Uygur V (2016) Uşak ili ceviz bahçelerinin mineral beslenme durumları. Süleyman Demirel Üniversitesi Ziraat Fakültesi Dergisi 11(2): 70-78. 